\title{
EFEKTIVITAS MANAJEMEN E-SYSTEM DALAM PELAYANAN PERPAJAKAN TERHADAP KEPATUHAN WAJIB PAJAK DALAM PELAPORAN SPT (E-FILING)
}

\author{
Pujo Gunarso ${ }^{1^{*}}$ \\ ${ }^{1}$ Fakultas Ekonomi dan Bisnis Universitas Merdeka Malang \\ *pujo.lelly@gmail.com
}

\begin{abstract}
This purposes of this study is to analyze the influence of management effectiveness of etaxation system to tax compliance in terms of reporting such as (e-filing). This research was conducted at the Tax Office Batu region in the tax year 2015. The research method uses a descriptive quantitative method. The results of this study explains that the management of efiling for the realization of the Key Performance Index e-filing using point based on the rules of the Directorate General of Taxation number: PER-03 / PJ / 2015 has been effective.
\end{abstract}

Keywords: E-filing, E-System, Taxpayer Compliance.

\section{PENDAHULUAN}

Penerimaan dari sektor pajak merupakan salah satu komponen penting dari seluruh penerimaan negara. Penerimaan pajak merupakan sumber pembiayaan negara yang dominan baik untuk belanja rutin maupun pembangunan (Suryadi, 2006). Besarnya kontribusi pajak dapat menjamin kestabilan bagi tersedianya sumber penerimaan negara. Pengelolaan pajak di Indonesia berkembang dengan dinamis melalui perubahan seperti organisasi, sistem, sarana dan prasarana kerja, peraturan maupun aparat yang mengelola pajak, yang telah memberikan kontribusi pada penerimaan negara.

Kepatuhan wajib pajak untuk melaksanakan kewajibanya membayar pajak adalah unsur yang sangat penting dalam menjamin kestabilan penerimaan dari sektor pajak. Data yang ada di Direktorat Jenderal Pajak menunjukkan bahwa dari 238 juta penduduk Indonesia, sekitar 44 juta orang dianggap layak membayar pajak. Tetapi dari jumlah itu hanya 8 juta orang yang memenuhi kewajiban perpajakannya. Dari sektor wajib pajak badan, yang tercatat di
Direktorat Jenderal Pajak terdapat 22.6 juta badan usaha baik yang berdomisili tetap maupun tidak, namun hanya 466 ribu badan usaha yang membayar pajak. Dari data tersebut bisa dilihat bahwa tingkat kepatuhan wajib pajak (tax compliance) dalam memenuhi kewajiban perpajakan masih sangat rendah(Tresno at al, 2013).

Sistem perpajakan di Indonesia menganut self assesment system, self assesment system adalah satu bentuk sistem pemungutan pajak dimana masyarakat sebagai wajib pajak diberi kepercayaan oleh pemerintah untuk menghitung sendiri besarnya pajak yang terutang dengan mengisi Surat Pemberitahuan (SPT). Sistem ini membuat kepatuhan sukarela (voluntary compliance) wajib pajak menjadi faktor yang sangat penting, karena faktor inilah wajib pajak tergerak untuk melaksanakan kewajibanya melaporkan SPT sampai melakukan pembayaran hutang pajaknya.

Penelitian tentang kepatuhan wajib pajak sudah banyak diteliti oleh peneliti pada kajian ilmu ekonomi perpajakan, penelitian Roades (1979) menekankan pada aspek pentingnya kesadaran dan kepatuhan wajib 
pajak dalam melaporkan pendapatan bersih, karena dari hasil penelitiannya menyimpulkan bahwa wajib pajak seringkali tidak memberikan pelaporan mengenai pendapatan bersihnya. Penerapan self assesment ini akan menjadi efektif apabila kondisi kepatuhan sukarela (voluntary compliance) pada masyarakat telah terbentuk (Damayanti, 2004).

Berdasarkan penelitian diatas kenyataan yang terdapat di Indonesia, menunjukkan bahwa tingkat kepatuhan masih rendah, hal ini dapat dilihat dari belum optimalnya penerimaan pajak yang tercermin dari tax gap dan tax ratio. Seperti yang di jelaskan pada Kompas Forum (2011) yang di kutip dari Aini at al. (2013), menjelaskan rendahnya tax ratio menandakan hilangnya potensi penerimaan negara yang dapat digunakan sebagai sumber pembiayaan belanja sosial dan pembangunan infrastruktur. Jika menggunakan taksiran konservatif, tax gap yang terjadi sebesar 3040 persen dengan potensi pajak sekurangkurangnya $\mathrm{Rp} 300$ triliun per tahun. Artinya, sekitar 35-40 persen potensi penerimaan pajak belum masuk ke kas negara. Hal ini menjadi indikasi penyebab dalam setiap pemeriksaan yang dilakukan terhadap wajib pajak seringkali menghasilkan surat ketetapan pajak (SKP) yang menyebabkan pajak yang seharusnya terutang lebih tinggi dibandingkan dengan pajak yang telah dibayar atau jumlah rugi yang lebih kecil daripada yang dilaporkan wajib pajak.

Berawal dari Keputusan Direktur Jenderal Pajak Nomor Kep-88/PJ/2004 secara resmi diluncurkan produk e-filling atau electronic filling system. E-filling yaitu sistem penyampaian Surat Pemberitahuan (SPT) secara elektronik yang dilakukan melalui sistem online dan real time melalui perusahaan penyedia jasa aplikasi yang ditunjuk oleh Dirjen Pajak. Seperti yang dijelaskan oleh Pandiangan (2007: 38) sistem $e$-filing adalah suatu cara penyampaian Surat Pemberitahuan (SPT) yang dilakukan melalui sistem online dan real time. Produk e-filling sebagian dari Produk e-system yang merupakan modernisasi perpajakan di Indonesia.

Produk e-system yang diluncurkan oleh DJP sebagai bentuk dari modernisasi perpajakan ialah dengan dibukanya fasilitas e-registration (pendaftaran NPWP secara online melalui internet), e-SPT (penyerahan SPT dalam media digital), dan e-filing (pengiriman SPT secara online melalui internet. Produk e-system terus melakukan perbaikan dan pembaharuan. Modernisasi administrasi perpajakan membuat jumlah wajib pajak pribadi juga meningkat tiap tahunnya.

Sehubungan dengan biaya kepatuhan wajib pajak, e-filling sangat membantu mengurangi biaya kepatuhan yang mempengarui tingkat kepatuhan wajib pajak. Sesuai yang dijelaskan Parwito (2009) dengan Sistem e-Filling membuat wajib pajak dapat mengurangi beban biaya pelaporan, mengurangi waktu pelaporan SPT, dan juga mengurangi dokumentasi yang digunakan oleh wajib pajak serta mengurangi kesalahan dalam memasukan data SPT.

Biaya kepatuhan menurut Simon dalam studi Robert Pakpahan dan Toyomu Yuasa (2004), compliance cost adalah "the costs to the private sector of complying with the requirement of a tax". Berdasarkan definisi tersebut compliance cost hanya meliputi biaya-biaya yang dikeluarkan oleh wajib pajak untuk memenuhi kewajibannya sesuai dengan peraturan perundangundangan yang berlaku. Kirchler (dalam Alabede, 2011: 128) menyatakan bahwa ketika wajib pajak mengeluarkan biaya untuk membayar pajak, terdapat risiko lebih tinggi yang akan membawa kepada ketidak patuhan wajib pajak. Maka dengan produk e-system yang diluncurkan oleh DJP diharapkan akan meningkatkan kepatuhan wajib pajak dalam melaksanakan kewajiban perpajakanya.

Penelitian sebelumnya yang sudah dilakukan tentang pengaruh e-system terhadap kepatuhan wajib pajak diantaranya penelitian dilakukan oleh Rysaka et al. (2014) yang meneliti tentang Penerapan 
Sistem Elektronik Dalam Pelayanan Perpajakan (Studi pada Kantor Pelayanan Pajak Pratama Malang Utara) dengan hasil penelitian yang menunjukkan bahwa pelaksanaan sistem elektronik perpajakan yang dilakukan Kantor Pelayanan Pajak Pratama Malang Utara tiap tahunnya mengalami kenaikan dalam penggunaan eSPT dan e-filing. Menurut Laihad (2013) yang meneliti tentang Pengaruh Perilaku Wajib Pajak Terhadap Penggunaan $e$-Filing Wajib Pajak di Kota Manado dengan hasil penelitian yang menunjukkan bahwa persepsi kegunaan berpengaruh positif dan signifikan terhadap penggunaan e-filing, persepsi kemudahan berpengaruh positif dan signifikan terhadap penggunaan e-filing dan sikap terhadap perilaku tidak berpengaruh terhadap penggunaan $e$-filing.

Berdasarkan uraian tersebut di atas penulis ingin meneliti modernisasi perpajakan, perubahan dan pengembangan sistem teknologi informasi, pengembangan aplikasi perpajakan yang ada di Indonesia kaitanya dengan kepatuhan wajib pajak, yaitu seberapa efektif pengelolaan e-system yang diluncurkan oleh Direktur Jenderal Pajak (DJP) dalam meningkatkan kepatuhan wajib pajak yang menggunakan parameter kepatuhan dalam melaporkan SPT (e-filing).

Dari latar belakang masalah seperti yang telah diuraikan sebelumnya, tujuan penelitian ini adalah untuk menganalisa keefektifan penggunaan e-system dalam pelayanan perpajakan terhadap kepatuhan wajib pajak dalam ketepatan pelaporan SPT (e-filing)

\section{Perpajakan Indonesia.}

Pengertian pajak menurut Dr. Soeparno Soemahamidjaja dalam Erly Suandy(2005) pajak merupakan iuran yang bersifat wajib, berupa uang atau barang, yang dipungut oleh pemerintah berdasarkan norma-norma hukum, yang digunakan untuk menutupi biaya produksi barang-barang dan jasa-jasa kolektif untuk mencapai kesejahteraan umum, Pengertian lainnya menurut Adriani dalam Sukardji (2005: 9) yaitu: Pajak adalah iuran kepada negara (yang dapat dipaksakan) yang tertutang oleh wajib pajak membayarnya menurut peraturan-peraturan, dengan baik tidak mendapat prestasi kembali yang langsung dapat ditunjuk dan yang gunanya adalah membiayai pengeluaranpengeluaran umum berhubungan dengan tugas negara untuk menyelenggarakan pemerintahan. Pengertian pajak dari uraian di atas dapat disimpulkan pajak adalah iuran pada negara yang dapat dipaksakan berdasarkan undang-undang tanpa jasa timbal balik secara langsung dan untuk membiayai pengeluaran umum pemerintah dan untuk pembangunan.

\section{Sistem Administrasi Perpajakan di Indonesia}

Administrasi pajak adalah cara dan prosedur untuk menghitung dan mengenakan pajak yang terhutang , seperti yang disampaikan oleh Lumbantoruan dalam Devano dan Kurnia (2006: 72) Administrasi perpajakan (tax administration) adalah caracara atau prosedur pengenaan dan pemungutan pajak. Sejak tahun 2002 Direktorat Jenderal Pajak (DJP) telah meluncurkan program perubahan (change program) atau reformasi administrasi perpajakan yang disebut modernisasi administrasi perpajakan. Sasaran penerapan sistem administrasi pajak modern adalah: pertama, maksimalisasi penerimaan pajak; kedua, kualitas pelayanan yang mendukung kepatuhan wajib pajak; ketiga, memberikan jaminan kepada publik bahwa Direktorat Jenderal Pajak mempunyai tingkat integritas dan keadilan yang tinggi, keempat, menjaga rasa keadilan dan persamaan perlakuan dalam proses pemungutan pajak; kelima, Pegawai Pajak dianggap sebagai karyawan yang bermotivasi tinggi, kompeten, dan profesional, keenam, peningkatan produktivitas yang berkesinambungan; ketujuh,Wajib Pajak mempunyai alat dan mekanisme untuk mengakses informasi yang diperlukan; kedelapan, optimalisasi pencagahan penggelapan paja (Dianasari dan Rachmawati, 2010) 


\section{Manajemen $\boldsymbol{E}$-system Dan $\boldsymbol{E}$-filling}

Produk e-filling adalah sebagian dari Produk e-system yang merupakan modernisasi perpajakan di Indonesia. Modernisasi mulai dilaksanakan oleh Direktur Jendral Pajak dengan diawali Keputusan Direktur Jenderal Pajak Nomor Kep-88/PJ/2004 secara resmi diluncurkan produk e-filling atau electronic filling system. E-filling yaitu sistem penyampaian Surat Pemberitahuan (SPT) secara elektronik yang dilakukan melalui sistem online dan real time melalui perusahaan penyedia jasa aplikasi yang ditunjuk oleh Dirjen Pajak. Seperti yang dijelaskan oleh Pandiangan (2007: 38) sistem $e$-filing adalah suatu cara penyampaian Surat Pemberitahuan (SPT) yang dilakukan melalui sistem online dan real time.

Produk e-system yang diterapkan oleh DJP dengan dibukanya fasilitas $e$ registration (pendaftaran NPWP secara online melalui internet), e-SPT (penyerahan SPT dalam media digital), dan e-filing (pengiriman SPT secara online melalui internet. Manajemen produk e-system terus dilakukan perbaikan dan pembaharuan.

\section{Kepatuhan Wajib Pajak}

Sistem perpajakan di Indonesia menganut self assesment system, self assesment system adalah satu bentuk sistem pemungutan pajak dimana masyarakat sebagai wajib pajak diberi kepercayaan oleh pemerintah untuk menghitung sendiri besarnya pajak yang terutang dengan mengisi Surat Pemberitahuan (SPT). Sistem ini membuat kepatuhan sukarela (voluntary compliance) wajib pajak menjadi faktor yang sangat penting, karena faktor inilah wajib pajak tergerak untuk melaksanakan kewajibanya melaporkan SPT sampai melakukan pembayaran Penerapan self assesment ini akan menjadi efektif apabila kondisi kepatuhan sukarela (voluntary compliance) pada masyarakat telah terbentuk (Damayanti, 2004).

\section{Pengaruh Modernisasi Sistem Perpajakan Terhadap Kepatuhan Wajib Pajak. \\ Modernisasi perpajakan yang}

diluncurkan oleh DJP dengan $e$-system dan $e$ filling diharapkan memberi kemudahan pada wajib pajak. Studi tentang pengaruh modernisasi pajak dengan kepatuhan wajib pajak diantaranya dilakukan oleh Rysaka et al. (2014) yang meneliti tentang Penerapan Sistem Elektronik Dalam Pelayanan Perpajakan dengan hasil penelitian yang menunjukkan bahwa pelaksanaan sistem elektronik perpajakan yang dilakukan Kantor Pelayanan Pajak Pratama Malang Utara tiap tahunnya mengalami kenaikan dalam penggunaan e-SPT dan e-filing. Rahayu dan Lingga (2009) dalam penelitiannya yang berjudul "Pengaruh Modernisasi Sistem Administrasi Perpajakan Terhadap Kepatuhan Wajib Pajak. Hasil penelitian tersebut menunjukan bahwa penerapan sistem administrasi perpajakan modern pada KPP Pratama Bandung "X" sebagian besar dalam kategori baik. Sistem administrasi perpajakan modern tidak memiliki pengaruh yang signifikan terhadap kepatuhan wajib pajak.

Peneliti berikutnya adalah Alabede at. al (2011) dalam penelitiannya yang berjudul "The Moderating Effect of Financial Condition on The Factors Influencing Tax Payers' Compliance Behaviour in Nigeria". Hasil penelitian tersebut menunjukan bahwa kondisi finansial terbukti memiliki efek moderasi. Tingkat kepatuhan wajib pajak sangat dipengaruhi oleh determinannya Saipei dan Abdullah (2008) dalam penelitiannya yang berjudul "The Compliance Cost of The Personal Income Taxation in Malaysia". Hasil penelitian tersebut menunjukan bahwa biaya terbesar yang harus dikeluarkan oleh wajib pajak perorangan adalah biaya waktu untuk menyimpan data-data atau dokumen perpajakan. Apabila mengacu pada biaya moneter, maka biaya terbesar yang harus dikeluarkan wajib pajak adalah biaya untuk menyewa konsultan pajak. 


\section{METODE.}

Metode penelitian ini menggunakan metode deskriptif kuantitatif, yaitu bersifat menjelaskan (explanatory research) dan mendeskripsikan suatu gejala, dengan dukungan data kuantitatif

\section{Ruang Lingkup Penelitian.}

Penelitian dilakukan di KPP Pratama Batu yang terletak di Jl. Letjend. S. Parman No. 100, Malang. Penelitian yang dilakukan mencakup bidang perpajakan khususnya tentang efektivitas manajemen e-system dalam pelayanan perpajakan terhadap kepatuhan wajib pajak dalam ketepatan pelaporan SPT (e-filing) di daerah Batu.

\section{Teknik Analisis Data}

Teknik analisis data yang dipergunakan untuk menganalisis yaitu menggunakan metode deskriptif kuantitatif, yaitu berupa gambaran atau karakteristik data, mendiskriptifkan variabel penelitian secara kualitatif berdasar data kuantitatif yang diperoleh

HASIL DAN PEMBAHASAN.

\section{Data Wajib Pajak Terdaftar di KPP} Pratama Batu

Berikut ini merupakan data mengenai jumlah wajib pajak orang pribadi di KPP Pratama Batu tahun 2015:

Tabel 1. Daftar Wajib Pajak Orang Pribadi Tahun 2015

\begin{tabular}{clc}
\hline No. & \multicolumn{1}{c}{ Keterangan } & Jumlah \\
\hline 1 & $\begin{array}{l}\text { Wajib Pajak Orang } \\
\text { Pribadi yang terdaftar }\end{array}$ & 12.520 \\
\hline 2 & $\begin{array}{l}\text { Wajib Pajak Orang } \\
\text { Pribadi yang wajib SPT }\end{array}$ & 9.748 \\
& \\
\hline 3 & $\begin{array}{l}\text { Tahunan } \\
\text { Pribadi Pajak Orang } \\
\text { memasukan }\end{array}$ & 8.336 \\
\end{tabular}

Sedangkan jumlah wajib pajak orang pribadi yang memasukan SPT tahunan dapat dilihat pada tabel berikut ini:
Tabel 2. Daftar uraian wajib pajak orang pribadi yang memasukan SPT Tahunan

\begin{tabular}{cll}
\hline No. & \multicolumn{1}{c}{ Keterangan } & Jumlah \\
\hline 1 & $\begin{array}{l}\text { SPT 1770S dan 1770SS } \\
\text { yang masuk tahun }\end{array}$ & 8.336 \\
& 2015 \\
\hline 2 & $\begin{array}{l}\text { Wajib Pajak lapor secara } \\
\text { manual }\end{array}$ & 5.001 \\
\hline 3 & $\begin{array}{l}\text { Wajib Pajak lapor } \\
\text { menggunakan } e \text {-filing }\end{array}$ & 3.335 \\
&
\end{tabular}

\section{Data Realisasi Indeks Kinerja Utama $e$ - filing menggunakan point berdasarkan aturan PER 03/PJ/2015}

Pada tahun 2015, total e-FIN yang terdaftar sejumlah 8.558, dimana 4.190 terdaftar sebelum tahun 2015 dan 4.368 yang terdaftar tahun 2015.

Perhitungan IKU (Indeks Kinerja Utama) efiling menggunakan point berdasarkan aturan yang dipakai PER 03/PJ/2015 tanggal 13 Februari 2015, dengan tata cara perhitungan point:

Tabel 3: Tata Cara Perhitungan Point

\begin{tabular}{clc}
\hline No. & \multicolumn{1}{c}{ Keterangan } & Point \\
\hline 1 & $\begin{array}{l}\text { Permohonan efin di } \\
\text { KPP Sendiri dan } \\
\text { masuk SPT } \\
\\
\\
\text { e-filing }\end{array}$ & \\
\hline 2 & Permohonan efin di & 0,8 \\
& KPP Lain dan masuk & \\
& SPT \\
& $e$-filing \\
\hline 3 & $\begin{array}{l}\text { Permohonan efin } \\
\text { punya KPP lain dan } \\
\text { masuk SPT } \\
\\
\text { e-filing }\end{array}$ & \\
\hline
\end{tabular}

Pada tahun 2015, prosentase pencapaian KPP Pratama Batu 122,75\%, dengan realisasi 3.237 dari target 2.637 point 


\section{Realisasi Penggunaan E-Filing Menggunakan Jumlah Pelapor SPT}

Untuk menghitung tingkat efektivitas dapat dilakukan dengan cara, membagi antara jumlah wajib pajak orang pribadi yang telah lapor secara e-filing dibandingkan dengan jumlah SPT yang masuk:

$\mathrm{C}=(\mathrm{A}: \mathrm{B}) * 100$

$\mathrm{C}=(3.335: 8.336)^{*} 100$

$\mathrm{C}=40 \%$

Keterangan:

$\mathrm{C}=$ Efektivitas

$\mathrm{A}=$ Jumlah wajib pajak lapor secara $e$-filing

$\mathrm{B}=$ Jumlah SPT yang masuk

Berdasarkan data dan uraian di atas dapat diketahui bahwa jika ditinjau dari jumlah SPT yang masuk, penggunaan $e$ filing ini dapat diartikan belum efektif, karena hanya $40 \%$ dari total SPT yang masuk. Hal ini terjadi karena tidak semua wajib pajak orang pribadi yang memasukan SPT dapat menggunakan e-filing, maksudnya adalah yang dapat menggunakan e-filing hanya wajib pajak yang menggunakan formulir SPT 1770 S dan 1770SS.

Adapun perbandingkan jumlah wajib pajak orang pribadi yang telah melapor secara $e$-filing dibandingkan dengan jumlah wajib pajak orang pribadi yang terdaftar dan jumlah wajib pajak orang pribadi yang wajib SPT Tahunan:



Setelah dilakukan perhitungan untuk kedua aspek diatas, dapat diketahui bahwa penggunaan $e$-filing belum efektif. Jika dibandingkan dengan jumlah wajib pajak orang pribadi yang terdaftar hanya sekitar 26,64\%. Jika dibandingkan dengan jumlah wajib pajak orang pribadi yang wajib SPT tahunan sekitar $34,21 \%$. Tidak efektifnya teknologi ini dikarenakan hal yang sama seperti jika kita membandingkan antara jumlah wajib pajak orang pribadi yang lapor secara $e$-filing dibandingkan dengan wajib pajak orang pribadi yang memasukan SPT Tahunan, yaitu yang dapat menggunakan $e$ filing sejauh ini hanyalah wajib pajak orang pribadi yang menggunakan formulir SPT 1770S dan 1770SS.

\section{Realisasi Indeks Kinerja Utama e-filing menggunakan point berdasarkan aturan PER 03/PJ/2015.}

Berdasarkan Indeks Kinerja Utama $e$ filing menggunakan point yang telah ditetapkan oleh peraturan Direktorat Jenderal Pajak dengan nomor: PER 03/PJ/2015 tanggal 13 Februari 2015, dapat diketahui bahwa target untuk KPP Pratama Batu sejumlah 2.637 point dan realisasi yang telah tercapai yaitu sejumlah 3.237 point, dapat ditarik kesimpulan bahwa persentase pencapaian point yang diperoleh KPP Pratama Batu untuk tahun 2015 mencapai $122,75 \%$. Hal ini berbanding terbalik dengan jumlah wajib pajak wajib SPT Tahunan karena sistem point tersebut yang membuat adalah Direktorat Jenderal Pajak dan berlaku bagi seluruh KPP yang ada di Indonesia, dan berdasarkan informasi petugas di KPP Pratama Batu bagian pelayanan, yang menyatakan bahwa setiap tahun target point yang ditetapkan oleh Direktorat Jenderal Pajak selalu mengalami peningkatan. Hal ini pula yang menyebabkan jumlah pelapor SPT menggunakan e-filing lebih sedikit, karena tidak semua yang mendaftarkan e-FIN yang akan menyetorkan kewajiban pajaknya ke KPP Pratama Batu. 


\section{KESIMPULAN DAN SARAN.}

Berdasarkan pembahasan diatas dapat disimpulkan: 1) Apabila dikaitkan dengan total SPT yang masuk manajemen penggunaan e-filing belum efektif dikarenakan hanya sebagian wajib pajak orang pribadi yang menggunakan formulir SPT 1770S dan 1770SS yang bisa menggunakan e-filling, belum menyeluruh bagi wajib pajak orang pribadi. Berdasarkan hasil data yang di analisis penggunaan $e$ filing ini dapat diartikan belum efektif, karena hanya $40 \%$ dari total SPT yang masuk, 2) Untuk realisasi Indeks Kinerja Utama e-filing menggunakan point berdasarkan aturan dari Direktorat Jenderal Pajak nomor: PER 03/PJ/2015 telah berjalan efektif, karena sudah melebihi target yang telah ditetapkan oleh Direktorat Jenderal Pajak.

Bagi peneliti selanjutnya dapat meneliti variabel yang lebih banyak kaitanya dengan modernisasi administrasi perpajakan terhadap kepatuhan wajib pajak dengan menggunakan analisis multiple linier regression untuk mengetahui pengaruh variabel modernisasi administrasi pajak terhadap kepatuhan wajib pajak.

Bagi Kantor Pelayanan Pajak sebagai salah satu unsur pemerintah yang menjebatani perpajakan di Indonesia hendaknya lebih kreatif dan aktif dalam menginformasikan dan mengelola kelebihan yang ditawarkan dari fasilitas e-filing, dengan demikian, akan lebih banyak Wajib Pajak yang mengetahui adanya fasilitas pelaporan SPT secara online, dan hal ini dapat meningkatkan jumlah pengguna fasilitas $e$-filing.

\section{DAFTAR PUSTAKA}

Alabede, Zainol and Idris. (2011). Tax Service Quality and Compliance Behaviour in Nigeria: Do Taxpayer's Financial Condition and Risk Preference Play Any Moderating Role. Journal of Economics, Finance and Administrative Sciences, ISSN 14502887 Issue 78 (2011)
Aini, Aldila Oktavi, Judi Budiman dan Provita Wijayanti. 2012. Kepatuhan Wajib Pajak Badan Perusahaan Manufaktur di Semarang dalam Perspektif TaxProfessional. Prosiding Simposium Nasional Perpajakan 4.

Damayanti, Theresia Woro, 2004. Pelaksanaan Self Assesment System Menurut Wajib Pajak (Studi Kasus pada Wajib Pajak Badan Salatiga). Jurnal Ekonomi dan Bisnis. Volume X No. 1, 109-128.

Direktorat Jenderal Pajak. 2005. KEP88/PJ/2004 Jo KEP-05/PJ/2005 dalam

Tata Cara Penyampaian Surat Pemberitahuan secara Elektronik Melalui Perusahaan Penyedia Jasa(ASP), 12 Januari 2005 diakses dari http://www.laporpajak.com/laporpajak/f iles/KEP-05-PJ-2005.pdf dan http://www.pajakindonesia.com/desc_en siklopedia.php? \&idb=482 pada tanggal 10 Oktober 2011

Devano, Sony, dan Rahayu, Siti Kurnia. (2006). Perpajakan: Konsep, Teori, dan Isu. Jakarta: Prenada Media Grup.

Dianasari dan Rachmawati, 2010, Pengaruh Modernisasi Administrasi Perpajakan Terhadap Pencapaian Akuntabilitas Pada KPP Modern. Universitas Widyatama

Hastuty, Endang Novi, dan Jenie, Siti Ismijati. (2006). Implementasi Elektronik Filing Sistem (E-Filing) Dalam Praktek Perpajakan di Indonesia. Sekolah Pascasarjana Universitas Gajah Mada, Jurnal SOSIOSAINS 19 (2) April 2006.

Jannah, Fury Fathul. 2014. Pengaruh Efektivitas Penggunaan Fasilitas EFiling Terhadap Kepuasan Wajib Pajak dalam Pelaporan SPT (Survey dilakukan pada Wajib Pajak yang Terdaftar sebagai Pengguna Fasilitas E-filing di Kantor Pelayanan Pajak Pratama Bandung Cicadas). Fakultas Ekonomi Universitas Pasundan

Laihad, Risal C.Y. 2013. Pengaruh Perilaku Wajib Pajak Terhadap Penggunaan EFiling Wajib Pajak di Kota Manado. 
Jurnal EMBA Vol.1 No.3 September 2013

Lingga, Ita Salsalina. 2012. Pengaruh Penerapan e-SPT Terhadap Efisiensi Pemrosesan Data Perpajakan: Survey Terhadap Pengusaha Kena Pajak pada KPP Pratama X, Bandung. Jurnal Akuntansi Vol.4 No.2 November 2012

Novrida, Nurhasanah Firmansyah Ima. 2015 . Pengaruh Persepsi Wajib Pajak Orang Pribadi Terhadap Penggunaan Electronic Filling (e-filling) di KPP Pratama Palembang Ilir Barat. Jurnal Akuntanika,No.1,Vol.1

Peraturan Direktur Jenderal Pajak Nomor PER-03/PJ/2015 tentang Penyampaian Surat Pemberitahuan Elektronik.

Pandiangan, Liberty. (2007). Reformasi Perpajakan. Jakarta: PT Salemba Empat.

Pakpahan, Robert, and Yuasa, Toyomu. (2004). Menuju Sistem dan Administrasi Perpajakan Berkelas Dunia. Jakarta: PT Kharisma Bintang Kreativitas Prima.

Parwito, Andri. (2009). Analisis Atas Pengaruh Pemanfaatan e-Filing Terhadap Cost of Compliance. Tesis Fakultas Ilmu Sosial dan Ilmu Politik, Departemen Ilmu Administrasi, Universitas Indonesia.

Pakpahan, Robert (2004) Kantor Pelayanan Pajak Percontohan, Dalam buku Menuju Sistem dan Administrasi Perpajakan Berkelas Dunia : Studi Perpajakan di indonesia dengan Inspirasi Pengalaman Jepang, ad. Robert Pakpahan dan Toyomu Yuasa, Jakarta: JICA dan DJP

Roades, shelly. C 1999, The Impact Of Mutiple Component Reporting on ax Compliance and Audit Strategis, The Accounting Review Vol 74. No. 1, January, P.63-85. Suandy, Erly. (2005). Hukum Pajak. Jakarta : Salemba Empat.

Rysaka, et al. 2014. Penerapan Sistem Elektronik Dalam Pelayanan Perpajakan (Studi pada Kantor Pelayanan Pajak Pratama Malang
Utara). Jurusan Administrasi Publik (JAP), Vol. 2. No. 3.

Suryadi. (2006). Model Hubungan Kausal Kesadaran, Pelayanan, Kepatuhan Wajib Pajak Dan Pengaruhnya Terhadap Kinerja Penerimaan Pajak.Jurnal Keuangan Publik, 4(1), 105-121.

Sukardji, Untung. (2005). Pajak Pertambahan Nilai Edisi Revisi. Jakarta: Raja Grafindo Persada

Tresno,. Pahala, Indra,. \& Rizky, Selvy Ayu. Pengaruh Persepsi Penerapan Sistem $e$ Filing Terhadap Tingkat Kepatuhan Wajib Pajak Badan Dengan Perilaku Wajib Pajak Sebagai Variabel Intervening Dan Biaya Kepatuhan Sebagai Variabel Moderasi. Prosiding Simposium Nasional Perpajakan 4. 